\title{
CANDIDATE GLASS-CERAMIC WASTE FORMS FOR IMMOBILIZATION OF THE CALCINES STORED AT THE IDAHO CHEMICAL PROCESSING PLANT
}

Krishna Vinjamuri

Idaho National Engineering Laboratory, Lockheed Idaho Technologies Company, P. O. Box 1625, Idaho Falls, Idaho 83415-5213

\begin{abstract}
Candidate glass-ceramic waste forms for immobilization of the major types of calcines stored at the Idaho Chemical Processing Plant (ICPP) were synthesized and characterized. The waste forms were prepared by hot isostatically pressing a mixture $70 \mathrm{wt} \%$ of precompacted simulated non-radioactive calcine and $30 \mathrm{wt} \%$ additives (Silica and Al or Ti metal powders). The types of calcines stored in stainless steel Bin Sets at the ICPP are fluorinel/sodium (FINa), alumina, zirconia, zirconia/sodium ( $\mathrm{Zr} / \mathrm{Na}$ ), and zirconia-alumina ( $\mathrm{Zr}$-AI). In addition to the silica additive, glass-ceramics for $\mathrm{F} / \mathrm{Na}$ and alumina calcines were prepared and characterized using ICPP soil and clay additives. The characteristics of the waste forms including density, elastic properties, chemical durability, glass and crystalline phases, phases separation, and the microstructure were investigated. The 28-day MCC-1 test for chemical durability was used for all the waste forms. In addition, the Product Consistency Test (PCT) was conducted for the glass-ceramics, and the normalized elemental releases in $\mathrm{g} / \mathrm{m}^{2}$ were compared with the Environmental Assessment (EA) glass. The characteristics of the soil and clay glass-ceramics appear to be as good as the waste forms prepared with silica. The glass-ceramic waste forms recommended are: 5Ti-Clay, or 5Ti-Soil, or 5Ti-Silica for the fluorinel/sodium calcine; clay or silica for the alumina calcine; and 5Ti-Silica for the zirconia, $\mathrm{Zr} / \mathrm{Na}$, and $\mathrm{Zr}-\mathrm{Al}$ calcines. Soiland clay-based glass-ceramics offer an opportunity to incorporate contaminated waste into durable low volume waste forms.
\end{abstract}

\section{DISCLAIMER}

This report was prepared as an account of work sponsored by an agency of the United States Government. Neither the United States Government nor any agency thereof, nor any of their employees, makes any warranty, express or implied, or assumes any legal liability or responsibility for the accuracy, completeness, or usefulness of any information, apparatus, product, or process disclosed, or represents that its use would not infringe privately owned rights. Reference herein to any specific commercial product, process, or service by trade name, trademark, manufacturer, or otherwise does not necessarily constitute or imply its endorsement, recommendation, or favoring by the United States Government or any agency thereof. The views and opinions of authors expressed herein do not necessarily state or reflect those of the United States Government or any agency thereof. 


\section{DISCLAIMER}

Portions of this document may be illegible electronic image products. Images are produced from the best available original document. 


\section{INTRODUCTION}

Since early the 80 s, durable glass-ceramics have been developed and characterized at the Idaho Chemical Processing Plant (ICPP). Glass-ceramics appear to be suitable waste forms for immobilization of the high level solid wastes, Fluorinel/sodium (F/Na), alumina, zirconia, zirconia/sodium $(\mathrm{Zr} / \mathrm{Na}$ ), and zirconia-alumina ( $\mathrm{Zr}-\mathrm{Al})$ calcines that are stored in stainless steel Bin Sets at the ICPP. Candidate glass-ceramic waste forms were synthesized at ICPP by hot isostatically pressing a mixture of precompacted non-radioactive simulated calcine and additives at $1050^{\circ} \mathrm{C}, 20,000 \mathrm{psi}$ for 4 hours. ${ }^{1-5}$ The calcine and the additive contents for the candidate waste forms for immobilization of the Fl/Na, alumina, zirconia, $\mathrm{Zr} / \mathrm{Na}$, and $\mathrm{Zr}-\mathrm{Al}$ calcines are given in Table I. The calcine waste loading was $70 \mathrm{w1} \%$. Additives include silica, soil, clay, aluminum metal powder, titanium metal powder, $\mathrm{Na}_{2} \mathrm{O}, \mathrm{B}_{2} \mathrm{O}_{3}$, and $\mathrm{Li}_{2} \mathrm{O}$. In addition to the silica additive, glass-ceramics for Fl $\mathrm{Na}$ and alumina calcines were prepared using ICPP soil and clay additives. The composition of the ICPP soil is given in Reference 5. The composition of clay is $73 \mathrm{wt} \% \mathrm{SiO}_{2}, 16.2 \mathrm{wt} \% \mathrm{Al}_{2} \mathrm{O}_{3}, 3.9 \mathrm{wt} \% \mathrm{Fe}_{2} \mathrm{O}_{3}, 2.7 \mathrm{wt} \% \mathrm{Na}_{2} \mathrm{O}, 2.2 \mathrm{wt} \% \mathrm{MgO}, 1.2 \mathrm{wt} \% \mathrm{~K}_{2} \mathrm{O}$, $0.6 \mathrm{wt} \% \mathrm{TiO}_{2}$, and $0.2 \mathrm{wt} \% \mathrm{CaO}$. Chemical composition of calcines (except for zirconia calcine), formulations for glass-ceramic waste forms, and experimental procedures are discussed

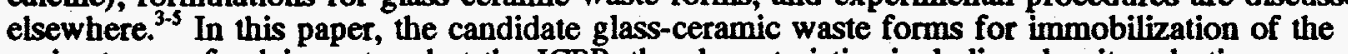
major types of calcines stored at the ICPP, the characteristics including density, elastic properties, chemical durability, glass and crystalline phases, phases separation, and the microstructure are discussed.

Table 1. Calcine and Additive Composition (w1\%)

\begin{tabular}{|c|c|c|c|c|c|c|c|c|c|}
\hline Waste Form & $\begin{array}{l}\text { Calcine } \\
\text { Type \& } \\
\text { Loading }\end{array}$ & Silica & Soil & Clay & $\mathrm{Al}$ & $\mathrm{Ti}$ & $\mathrm{Na} 2 \mathrm{O}$ & $\mathrm{B}_{2} \mathrm{O}_{3}$ & $\mathrm{Li} 2 \mathrm{O}$ \\
\hline FI/Na 2Al-Silica & $\begin{array}{l}\text { FINa } \\
70.0\end{array}$ & 28.0 & 0.0 & 0.0 & 2.0 & 0.0 & 0.0 & 0.0 & 0.0 \\
\hline Fl/Na 2Al-Soil & $\begin{array}{c}\text { Fl/Na } \\
70.0\end{array}$ & 0.0 & 28.0 & 0.0 & 2.0 & 0.0 & 0.0 & 0.0 & 0.0 \\
\hline FI/Na 2Al-Clay & $\begin{array}{l}\mathrm{F} / \mathrm{Na} \\
70.0\end{array}$ & 0.0 & 0.0 & 28.0 & 2.0 & 0.0 & 0.0 & 0.0 & 0.0 \\
\hline FYNa STi-Silica & $\begin{array}{l}\text { FINa } \\
70.0\end{array}$ & 23.9 & 0.0 & 0.0 & 0.0 & 5.0 & 0.0 & 1.1 & 0.0 \\
\hline Fl/Na 5Ti-Soil & $\begin{array}{l}\text { Fl/Na } \\
70.0\end{array}$ & 0.0 & 23.9 & 0.0 & 0.0 & 5.0 & 0.0 & 1.1 & 0.0 \\
\hline FINa STi-Clay & $\begin{array}{l}\text { F/Na } \\
70.0\end{array}$ & 0.0 & 0.0 & 23.9 & 0.0 & 5.0 & 0.0 & 1.1 & 0.0 \\
\hline Alumina Silica & $\begin{array}{l}\text { Alumina } \\
70.0\end{array}$ & 30.0 & 0.0 & 0.0 & 0.0 & 0.0 & 0.0 & 0.0 & 0.0 \\
\hline Alumina Soil & $\begin{array}{c}\text { Alumina } \\
70.0\end{array}$ & 0.0 & 30.0 & 0.0 & 0.0 & 0.0 & 0.0 & 0.0 & 0.0 \\
\hline Alumina Clay & $\begin{array}{c}\text { Alumina } \\
70.0\end{array}$ & 0.0 & 0.0 & 30.0 & 0.0 & 0.0 & 0.0 & 0.0 & 0.0 \\
\hline $\begin{array}{l}\text { Zirconia } \\
\text { STi-Silice }\end{array}$ & $\begin{array}{c}\text { Zirconia } \\
70.0\end{array}$ & 20.2 & 0.0 & 0.0 & 0.0 & 5.0 & 2.2 & 1.8 & 0.8 \\
\hline ZrNa STi-Silica & $\begin{array}{c}\mathrm{Zr} / \mathrm{Na} \\
70.0\end{array}$ & 21.8 & 0.0 & 0.0 & 0.0 & 5.0 & 1.6 & 1.6 & 0.0 \\
\hline Zr-AP 5Ti-Silica & $\begin{array}{c}\mathrm{Zr} / \mathrm{Al} \\
70.0\end{array}$ & 20.1 & 0.0 & 0.0 & 0.0 & 5.0 & 2.3 & 1.8 & 0.8 \\
\hline
\end{tabular}

- Zirconia and alumina calcines in Bin Set II.

\section{RESULTS, DISCUSSION, AND CONCLUSIONS}

The nominal chemical compositions of the waste forms and Young's modulus are given in Table II. Silica ranges between $16 \mathrm{wt} \%$ for the Fl/Na STi-Soil waste form and $30 \mathrm{wt} \%$ for the 
Table II. Nominal Composition of the Waste Forms in wt\% And the Young's Modulus in GPa.

\begin{tabular}{|c|c|c|c|c|c|c|c|c|c|c|c|c|}
\hline Waste Form & $\begin{array}{c}\text { FyNa } \\
2 A \text { L } \\
\text { Silica } \\
\end{array}$ & $\begin{array}{l}\text { F/Na } \\
2 \mathrm{Al} \\
\text { Soil } \\
\end{array}$ & $\begin{array}{l}\mathrm{F} / \mathrm{Na} \\
2 \mathrm{Al}- \\
\mathrm{Clay} \\
\end{array}$ & $\begin{array}{c}\text { FuNa } \\
\text { STi- } \\
\text { Silica } \\
\end{array}$ & $\begin{array}{c}\text { FyNa } \\
\text { 5Ti- } \\
\text { Soil } \\
\end{array}$ & $\begin{array}{l}\text { FINa } \\
\text { STi- } \\
\text { Clay } \\
\end{array}$ & $\begin{array}{c}\text { Alumina } \\
\text { Silica } \\
\end{array}$ & $\begin{array}{c}\text { Alumina } \\
\text { Soil }\end{array}$ & $\begin{array}{c}\text { Alumina } \\
\text { Clay } \\
\end{array}$ & $\begin{array}{c}\text { Zirconia- } \\
5 T_{j-} \\
\text { Silica } \\
\end{array}$ & $\begin{array}{c}\mathrm{Zr} / \mathrm{Na} \\
\text { 5Ti- } \\
\text { Silica } \\
\end{array}$ & $\begin{array}{c}\mathrm{Zr} \text { r-Al } \\
\text { STi- } \\
\text { silica } \\
\end{array}$ \\
\hline $\mathrm{Al}_{2} \mathrm{O}_{3}$ & 8.4 & 12.3 & 13.9 & 5.7 & 9.0 & 9.6 & 64.1 & 68.2 & 68.9 & 10.0 & 12.6 & 24.4 \\
\hline $\mathrm{B}_{2} \mathrm{O}_{3}$ & 3.1 & 3.1 & 3.0 & 4.1 & 3.0 & 3.0 & 0.4 & 0.4 & 0.4 & 1.9 & 1.8 & 2.5 \\
\hline $\mathrm{CaF}_{2}$ & 24.4 & 24.4 & 24.2 & 23.9 & 23.8 & 23.8 & 1.2 & 1.2 & 1.2 & 23.7 & 26.4 & 17.6 \\
\hline $\mathrm{Cl}_{2} \mathrm{O}$ & 8.0 & 9.8 & 7.9 & 7.8 & 9.3 & 7.8 & 0.4 & 2.3 & 0.5 & 18.0 & 12.0 & 13.2 \\
\hline CdO & 2.8 & 2.8 & 2.7 & 2.7 & 2.7 & 2.7 & 0.0 & 0.0 & 0.0 & 0.03 & 0.03 & 0.07 \\
\hline $\mathrm{CeO}_{2}$ & 0.7 & 0.7 & 0.7 & 0.7 & 0.7 & 0.7 & 0.0 & 0.0 & 0.0 & 0.07 & 0.01 & 0.07 \\
\hline $\mathrm{Cr}_{2} \mathrm{O}_{3}$ & 0.8 & 0.8 & 0.8 & 0.8 & 0.8 & 0.8 & 0.1 & 0.1 & 0.1 & 0.5 & 0.5 & 0.4 \\
\hline $\mathrm{Cs}_{2} \mathrm{O}$ & 0.1 & 0.1 & 0.1 & 0.1 & 0.1 & 0.1 & 0.4 & 0.4 & 0.4 & 0.2 & 0.07 & 0.3 \\
\hline $\mathrm{Fe}_{2} \mathrm{O}_{3}$ & 0.2 & 1.6 & 1.3 & 0.2 & 1.4 & 1.1 & 0.4 & 1.9 & 1.6 & 0.1 & 0.07 & 0.2 \\
\hline $\mathrm{K}_{2} \mathrm{O}$ & 1.2 & 1.5 & 1.5 & 1.1 & 1.4 & 1.4 & 0.1 & 0.5 & 0.5 & 0.0 & 0.6 & 0.1 \\
\hline $\mathrm{MgO}$ & 0.0 & 1.0 & 0.6 & 0.5 & 1.3 & 0.5 & 0.0 & 1.6 & 0.7 & 0.0 & 0.0 & 0.0 \\
\hline $\mathrm{Na}_{2} \mathrm{O}$ & 3.7 & 4.2 & 4.4 & 3.6 & 4.0 & 4.2 & 1.8 & 2.3 & 2.6 & 2.4 & 4.0 & 2.4 \\
\hline $\mathrm{SiO}_{2}$ & 27.8 & 18.4 & 20.1 & 23.2 & 16.0 & 17.7 & 30.0 & 19.9 & 21.9 & 20.1 & 21.6 & 20.1 \\
\hline Sro & 0.4 & 0.4 & 0.4 & 0.4 & 0.4 & 0.4 & 0.0 & 0.5 & 0.5 & 0.6 & 0.1 & 0.6 \\
\hline $\mathrm{TiO}_{2}$ & 0.0 & 0.2 & 0.2 & 7.8 & 8.2 & 8.2 & 0.0 & 0.2 & 0.2 & 5.8 & 5.8 & 5.8 \\
\hline $\mathrm{ZrO}_{2}$ & 11.7 & 11.7 & 11.6 & 11.5 & 11.4 & 11.4 & 0.6 & 0.6 & 0.6 & 15.8 & 13.9 & 11.7 \\
\hline Misc. & 6.5 & 6.8 & 6.4 & 6.3 & 6.3 & 6.3 & 0.0 & 0.0 & 0.0 & 0.0 & 0.7 & 0.0 \\
\hline $\begin{array}{l}\text { Young's } \\
\text { modulus }\end{array}$ & 64.8 & 75.8 & 75.8 & 78.6 & 84.8 & 77.2 & 101.0 & & & 82.1 & 68.3 & \\
\hline
\end{tabular}


alumina waste form. Iron and magnesium contents were high in the clay and soil waste forms compared to the waste forms prepared with silica. The Young's modulus of these waste forms ranged between 65 and $101 \mathrm{GPa}$ (9.4 and 14.6 million psi). The Young's moduli of the Fl/NaSoil waste forms are higher, and thus stronger than the FlNa-Silica waste forms. The Young's modulus for the alumina-silica is the highest at $101 \mathrm{GPa}$ (14.6 million psi). The Young's modulus is related to the strength and the thermal expansion coefficient of the material. Higher the Young's modulus, higher the material strength, and lower the thermal expansion coefficient. The densities of the waste forms for $\mathrm{Fl} / \mathrm{Na}$, alumina, zirconia, $\mathrm{Zr} / \mathrm{Na}$, and $\mathrm{Zr} / \mathrm{Al}$ calcines are 3.2, $3.0,3.1,2.9$, and $3.1 \mathrm{~g} / \mathrm{cm}^{3}$, respectively.

The 28-day MCC-1 test ${ }^{6}$ for chemical durability was used for all the waste forms. In addition, the 7-day Product Consistency Test $\left(\mathrm{PCT}^{7}\right.$ was conducted for the glass-ceramics. The 28-day MCC-1 total mass loss rates (TMIRs) and the normalized elemental leach rates are presented in Table III. The TMLRs for these waste forms ranged between 0.01 and $0.20 \mathrm{~g} / \mathrm{m}^{2}-\mathrm{day}$. It appears that the TMLRs for the FL/Na waste forms are independent of the additives, silica, or soil, or clay, or Al, or Ti. For the soil and clay alumina waste forms, the TMLRs are significantly lower compared to the alumina-silica waste forms. The 28-day MCC-1 normalized elemental leach rates for aluminum, boron, calcium, cadmium, chromium, cesium, potassium, silicon, sodium, strontium, titanium, and zirconium are all less than $1 \mathrm{~g} / \mathrm{m}^{2}$-day, except for the waste forms alumina-soil and $\mathrm{Zr}-\mathrm{Al}$ STi-Silica. For these two waste forms, the boron and the alkali leach rates are $>1 \mathrm{~g} / \mathrm{m}^{2}$-day. The 7-day PCT was conducted for the crushed glassceramic powders of 100-200 mesh. The volume of the leachant solution (deionized water) was $40 \mathrm{~mL}$ per gram of the crushed glass-ceramic. The surface area to the volume ratio (SA/V) was about $444 / \mathrm{m}$. The PCT normalized elemental releases in $\mathrm{g} / \mathrm{m}^{2}$ are compared with the Environmental Assessment (EA) glass in Table IV. The PCT normalized elemental releases for the glass-ceramics appear significantly lower than that of the EA glass. The SA/V for the EA glass was $2000 / \mathrm{m}$. The 28-day MCC-1 and the 7-day PCT results provide information about the short term corrosion rate. Thre is a need to perform long term MCC-1 or PCT corrosion tests or the vapor hydration test for accelerated long term corrosion. However, it is cautioned that the changes in particle size distribution and the glass and crystalline phase distributions may impact the PCT estimates. If the releases are from the glass matrix only, then the SA/V is to be corrected for the fraction of the glass surface area given in Table III. The releases presented in Tables III and IV are for the glass-ceramic surface area rather than for the glass matrix only.

The XRD results are presented in Table $V$. The major crystalline phases for all the waste forms, except for the alumina waste forms, are calcium fluoride and zirconia. In addition for the $\mathrm{F} / \mathrm{Na}$ waste forms the crystalline phases include, cadmium sulphide, zircon, and titanates. The crystalline phases for the alumina waste forms are alpha, gamma, and delta alumina, cristobalite, albite, and mullite. The additional crystalline phases for the zirconia waste form are zirconolite, and zircon. For $\mathrm{Zr} / \mathrm{Na}$, the additional phases are $\mathrm{Ca}_{2} \mathrm{Zr}_{3} \mathrm{Ti}_{2} \mathrm{O}_{6}$, and $\mathrm{Ca}_{2} \mathrm{SiO}_{4}$. The zircon crystals and the titanates (zirconolite, perovskite, and titanium oxides) have the capacity to host actinides, and the fission products, cesium and strontium, respectively.

The microstructure for the Fl/Na waste form includes glassy regions that are devoid of macro crystalline grains; the alumina waste forms consist of rod like alumina crystals in a glassy matrix, and the zirconia waste form is similar to the FINa waste form. The crystalline phases, except nephelene ( $\mathrm{NaA} \mid \mathrm{SiO}_{4}$ ), appear durable (see Table III for $\mathrm{Na}$ leach rates for $\mathrm{Zr}-\mathrm{Al}$ ). Glass phase separation was not detected in alumina and zirconia waste forms. In general, the glass and crystalline phases appear to be chemically durable, as the 28-day MCC-1 normalized elemental leach rates are less than $1 \mathrm{~g} / \mathrm{m}^{2}$-day. The characteristics of the soil and clay glassceramics are as good as the waste forms prepared with silica.

The recommended candidate glass-ceramic waste forms for immobilization of the major types of calcines stored at the ICPP are: FINa 5Ti-(Clay, or Soil, or Silica), Alumina-Silica, or -Clay, Zirconia-5Ti-Silica, Zr/Na-5Ti-Silica, and Zr-Al-5Ti-Silica, respectively. The waste 
Table III. The TMLRs, the Glass Surface Area Fraction, and the 28-day Normalized Elemental MCC-1 Leach Rates in $\mathrm{g} / \mathrm{m}^{2}$-day.

\begin{tabular}{|c|c|c|c|c|c|c|c|c|c|c|c|c|}
\hline Waste Porm & $\begin{array}{c}\text { TMLR" } \\
\text { GlassArea" }\end{array}$ & $\mathbf{A l}^{\mathbf{b}}$ & $\mathbf{B}^{\mathbf{b}}$ & $\mathrm{Ca}^{\mathrm{b}}$ & $\mathrm{Cd}^{\mathrm{b}}$ & $\mathrm{Cr}^{\circ}$ & $\mathrm{Cs}^{\mathrm{b}}$ & $\mathbf{K}^{\mathbf{b}}$ & $\mathbf{N a}^{\mathbf{b}}$ & $\mathrm{Si}^{\mathrm{b}}$ & $\mathbf{S r}^{b}$ & $\mathbf{T i}^{\mathrm{b}}$ \\
\hline $\begin{array}{l}\text { F/Na } \\
\text { 2Al-Silica }\end{array}$ & $\begin{array}{l}0.13 \\
0.27\end{array}$ & 0.26 & 0.08 & 0.15 & 0.10 & 0.03 & 0.00 & 0.17 & 0.20 & 0.36 & 0.30 & c \\
\hline $\begin{array}{l}\text { FL/Na } \\
\text { 2Al-Soil }\end{array}$ & $\begin{array}{l}0.16 \\
0.42\end{array}$ & 0.28 & 0.11 & 0.14 & 0.04 & 0.07 & 0.13 & 0.58 & 0.46 & 0.15 & 0.61 & ${ }^{c}$ \\
\hline $\begin{array}{l}\text { Fl/Na } \\
\text { 2Al-Clay }\end{array}$ & $\begin{array}{l}0.15 \\
0.29\end{array}$ & 0.22 & 0.04 & 0.13 & 0.04 & 0.06 & 0.00 & 0.31 & 0.22 & 0.13 & 0.41 & $\mathrm{c}^{\mathrm{c}}$ \\
\hline $\begin{array}{l}\text { FlNa } \\
\text { STi-Silica }\end{array}$ & $\begin{array}{l}0.15 \\
0.34\end{array}$ & 0.22 & 0.08 & 0.14 & 0.03 & 0.03 & 0.31 & 0.32 & 0.77 & 0.27 & 0.32 & 0.00 \\
\hline $\begin{array}{l}\text { FyNa } \\
\text { STi-Soil }\end{array}$ & $\begin{array}{l}0.17 \\
0.38\end{array}$ & 0.28 & 0.08 & 0.13 & 0.04 & 0.07 & 0.15 & 0.48 & 0.39 & 0.17 & 0.45 & 0.02 \\
\hline $\begin{array}{l}\text { Fl/Na } \\
\text { 5Ti-Clay }\end{array}$ & $\begin{array}{l}0.17 \\
0.33\end{array}$ & 0.26 & 0.07 & 0.14 & 0.03 & 0.07 & 0.13 & 0.47 & 0.51 & 0.17 & 0.43 & 0.02 \\
\hline Alumina Silica & 0.08 & 0.01 & 0.36 & d & 0.00 & 0.00 & 0.28 & 0.02 & 0.26 & 0.19 & 0.26 & c \\
\hline Alumina Soil & 0.02 & 0.04 & 9.63 & 0.01 & 0.00 & 0.00 & 1.01 & 1.18 & 3.49 & 0.21 & 0.00 & 0.00 \\
\hline Alumina Clay & 0.01 & 0.01 & 0.37 & 0.37 & 0.00 & 0.00 & 0.20 & 0.34 & 0.17 & 0.09 & 0.21 & 0.01 \\
\hline $\begin{array}{l}\text { Zirconia } \\
\text { 5Ti-Silica }\end{array}$ & $\begin{array}{l}0.20 \\
0.30\end{array}$ & 0.43 & 0.62 & & 0.03 & 0.01 & 0.37 & 0.05 & 0.42 & 0.39 & $\begin{array}{c}0.32 \\
0\end{array}$ & 0.00 \\
\hline $\begin{array}{l}\mathrm{Zr/Na} \text { 5Ti- } \\
\text { Silica }\end{array}$ & $\begin{array}{l}0.17 \\
0.34\end{array}$ & 0.41 & 0.16 & 0.14 & 0.00 & 0.00 & 0.00 & 0.39 & 0.66 & $\begin{array}{c}0.15 \\
d\end{array}$ & o & 0.02 \\
\hline $\begin{array}{l}\text { Zr-Ar 5Ti- } \\
\text { Silica } \\
\end{array}$ & 0.02 & 0.34 & 2.09 & 0.07 & d & 0.00 & 1.39 & 0.46 & 1.21 & d & 0.09 & d \\
\hline
\end{tabular}


Table IV. Comparison of the 7-day PCT Normalized Elemental Releases in $\mathrm{g} / \mathrm{m}^{2}$ With EA Glass

\begin{tabular}{|c|c|c|c|c|c|c|c|c|c|c|c|}
\hline Waste Form & Al & B & $\mathrm{Ca}$ & Cd & $\mathrm{Cr}$ & Cs & $\mathbf{K}$ & $\mathrm{Na}$ & $\mathrm{Si}$ & $\mathrm{Sr}$ & $\mathbf{T i}$ \\
\hline FI/Na 2Al-Silica & 0.17 & 0.23 & 0.11 & 0.00 & 0.01 & 0.05 & 1.90 & 1.34 & 0.10 & 0.00 & \\
\hline Fl/Na 2Al-Soil & 0.21 & 0.33 & 0.26 & 0.00 & 0.00 & 1.03 & 0.65 & 0.64 & 0.08 & 0.00 & \\
\hline Fl/Na 2Al-Clay & 0.13 & 0.24 & 0.14 & 0.01 & 0.00 & 0.05 & 0.31 & 0.38 & 0.09 & 0.00 & \\
\hline FINa STi-Silica & 0.29 & 0.47 & 0.14 & 0.01 & 0.01 & 0.39 & 0.21 & 0.64 & 0.02 & 0.00 & 0.00 \\
\hline F//Na 5Ti-Soil & 0.20 & 0.62 & 0.16 & 0.00 & 0.01 & 0.37 & 0.48 & 0.64 & 0.10 & 0.08 & 0.00 \\
\hline FINa 5Ti-Clay & 0.16 & 0.59 & 0.16 & 0.00 & 0.01 & 0.32 & 0.45 & 0.64 & 0.10 & 0.06 & 0.00 \\
\hline Alumina Silica & 0.17 & 0.32 & 0.07 & 0.00 & 0.00 & 0.85 & 0.01 & 0.24 & 0.11 & 0.00 & \\
\hline $\begin{array}{l}\text { Zirconia } \\
\text { 5Ti-Silica }\end{array}$ & 0.17 & 0.88 & 0.19 & 0.00 & 0.00 & 1.06 & 0.02 & 0.42 & 0.06 & 0.67 & \\
\hline EA Glass & & 4.54 & & & & & & 3.58 & 1.04 & & \\
\hline
\end{tabular}

- Surface Area/Volume $=444 \mathrm{~m}^{-1}$ for the glass-ceramics, and $2000 \mathrm{~m}^{-1}$ for the EA glass

If the releases are from glass matrix only, then the SA/V is to be corrected using the glass surface area fractions given in Table III. 
Table V. XRD Results For The Waste Forms (Relative abundance in w1\%)

\begin{tabular}{|c|c|c|c|c|c|c|c|c|c|c|c|}
\hline Waste Form & $\mathrm{CaF}_{2}$ & $\mathrm{ZrO}_{2}$ & $\mathrm{CdS}$ & ZrSiO, & $\mathrm{Ca}\left(\mathrm{Al}_{2}, \mathrm{Si}_{2}\right)_{2} \mathrm{O}_{2}$ & $\mathrm{NaAlSi}_{3} \mathrm{O}_{8}$ & $\mathrm{NaCaAlSi}_{2}$ & $\mathrm{Ca}_{2} \mathrm{SiO}_{2}$ & $\mathrm{CaZrTi}_{2} \mathrm{O}_{2}$ & $\mathrm{Cd}$ & CaTiSiO, $_{2}$ \\
\hline $\begin{array}{l}\text { Fr/Na } \\
\text { 2Al-Silica }\end{array}$ & 33.8 & 30.3 & & 11.4 & 6.0 & 10.1 & & & & & \\
\hline $\begin{array}{l}\text { FINAa } \\
\text { 2AI-Soil }\end{array}$ & 53.5 & 28.2 & 3.8 & & & 5.6 & 5.6 & 2.3 & & & \\
\hline $\begin{array}{l}\text { FiNa } \\
\text { 2Al-Clay }\end{array}$ & 55.7 & 21.3 & 4.4 & & & & & & & & \\
\hline $\begin{array}{l}\text { FyNa: } \\
\text { 5Ti-Silica }\end{array}$ & 36.8 & 17.2 & & 14.4 & & & & & & 3.1 & 15.6 \\
\hline $\begin{array}{l}\text { FlNa } \\
\text { STi-Soil }\end{array}$ & 43.5 & 17.6 & 4.1 & & & & & & 20.7 & 7.8 & 6.2 \\
\hline $\begin{array}{l}\text { Fl/Na } \\
\text { STi-Clay }\end{array}$ & 35.7 & 16.6 & 2.1 & & & & & & 17.8 & 6.7 & 2.7 \\
\hline $\begin{array}{l}\text { Zirconia } \\
\text { STi-Silica }\end{array}$ & 32.5 & 19.2 & 5.6 & 3.9 & $\begin{array}{c}\text { Anorthite } \\
15.8\end{array}$ & $\begin{array}{c}\mathrm{CaTiO}_{3} \\
4.2\end{array}$ & $\begin{array}{c}\mathrm{NaAlSi} \mathrm{i}_{2} \mathrm{O}_{6} \\
\end{array}$ & & 10.6 & $\begin{array}{l}\text { TiS } \\
1.8\end{array}$ & \\
\hline $\begin{array}{l}\mathrm{Z} \text { IINa } \\
\text { STi-Silica }\end{array}$ & 54.7 & 24.3 & & & $\begin{array}{c}\mathrm{Ca}_{2} \mathrm{Zr}_{5} \mathrm{Ti}_{2} \mathrm{O}_{6} \\
\end{array}$ & $\underset{3.1}{\mathrm{Ca}_{3} \mathrm{SiO}_{4}}$ & & & 3.3 & & 12.5 \\
\hline $\begin{array}{l}\text { Zr-Al } \\
\text { STi-Silica }\end{array}$ & 52.6 & 10.8 & & $\begin{array}{c}\text { Alpha } \\
\mathrm{Al}_{2} \mathrm{O}_{3} \\
3.9\end{array}$ & $\begin{array}{c}\mathrm{CaAl}_{2} \mathrm{Si}_{2} \mathrm{O}_{3} \\
21.6\end{array}$ & $\begin{array}{c}\mathrm{NaAlSiO}_{4} \\
8.6\end{array}$ & $\begin{array}{c}\mathrm{CaTiO}_{3} \\
2.4\end{array}$ & & & & \\
\hline $\begin{array}{l}\text { Alumina } \\
\text { Silica }\end{array}$ & & & & $\begin{array}{l}\mathrm{SiO}_{2} \\
35.3\end{array}$ & $\begin{array}{l}\text { Alpha } \\
\text { Alumina } \\
35.0\end{array}$ & $\underset{3.8}{\text { Gamma }}$ & $\begin{array}{c}\text { Delta } \\
\text { Alumina } \\
5.4\end{array}$ & $\begin{array}{c}\mathrm{Al}_{6} \mathrm{Si}_{2} \mathrm{O}_{13} \\
8.0\end{array}$ & $\begin{array}{c}\mathrm{CaAl}_{2} \mathrm{Si}_{2} \mathrm{O}_{8} \\
2.8\end{array}$ & & $\begin{array}{c}\mathrm{NaAlSi}_{3} \mathrm{O}_{3} \\
6.9\end{array}$ \\
\hline Alumina Clay & & & & & 86.0 & & & & & & 12.4 \\
\hline $\begin{array}{l}\text { Alumina } \\
\text { Soil } \\
\end{array}$ & & & & & 71.6 & $\begin{array}{c}\text { Anorthite } \\
18.8\end{array}$ & $\begin{array}{l}\text { Biotite }^{\mathrm{b}} \\
6.9\end{array}$ & & $\begin{array}{c}\text { Hercynite } \\
2.7\end{array}$ & & \\
\hline $\begin{array}{l}\text { a. Anorthite: } \\
\text { b. Biotile: } K \\
\text { c. Hercynite: }\end{array}$ & & & & & & & & & & & \\
\hline
\end{tabular}


forms prepared with clay or soil are cost effective compared to the waste forms prepared with silica. ${ }^{3}$ Soiland clay-based glass-ceramics offer an opportunity to incorporate contaminated waste into durable low volume waste forms. The PCT appears to be a viable test for the glass-ceramic waste forms also. However, the effects of particle size distribution, and the glass matrix and crystalline phase distribution on releases are to be investigated.

\section{ACKNOWLEDGEMENTS}

This work is sponsored by the U.S. Department of Energy, Idaho Operations Office, under contract No. DEAC07-94ID13223. The author wishes to thank D. V. Miley for SEM examination, Professor David Howith, University of California, Davis, for SEM and TEM examination, $H$. C. Wood for hot isostatic pressing of the waste formulations, R. P. Bopp, B. A. Scholes, and P. A. Tullock for sample preparation and MCC-1 leach testing, E. S. Dickerson and B. R. Boyle for XRD, D. A. Pavlica and his associates for chemical analyses of leachates, Ina Moore for formatting the draft, and B. A. Staples for presenting the paper at the American Ceramic Society Meeting.

\section{REFERENCES}

1. Krishna Vinjamuri, "Durability, Mechanical, and Thermal Properties of Experimental Glass-Ceramic Forms For Immobilizing ICPP High Level Waste," 1991 International High-Level Radioactive Waste Management Conference, April 28-May 3, 1991, Las Vegas, Nevada.

2. Krishna Vinjamuri et al., "Waste Form Development For Immobilization of High Level Waste Calcine at the Idaho Chemical Processing Plant," 1992 International High-Level Radioactive Waste Management Conference, April 12-16, 1992, Las Vegas, Nevada.

3. Krishna Vinjamuri, "Effect of Aluminum And Silicon Reactants And HIP Soak Time on Characteristics of Glass-Ceramic Waste Forms," presented at the 95th American Ceramic Society Symposium, April 1993, Indianapolis, Indiana, Published in the Ceramic Transactions Volume 45, Environmental and Waste Management Issues in the Ceramic Industry II, 1994.

4. Krishna Vinjamuri, "Glass-Ceramic Waste Forms for Immobilization of the Fluorinel-Sodium, Alumina, and Zirconia Calcines Stored at the Idaho Chemical Processing Plant," Proceedings of the 96th American Ceramic Society Symposium, April 24-28, 1994, Indianapolis, Indiana, Ceramic Transactions Volume 45, Environmental and Waste Management Issues in the Ceramic Industry II, 1994.

5. Krishna Vinjamuri, "Soil Based Glass-Ceramic Waste Forms For Immobilization of Fluorinel/Sodium Calcined High-Level Waste Stored at the Idaho Chemical Processing Plant," Proceedings of the International Topical Meeting on Nuclear and Hazardous Waste Management SPECTRUM '94.

6. J. E. Mendel (editor), Nuclear Waste Materials Handbook: Test Methods, DOE/TIC-1400, September 1983.

7. N. E. Bibler and C. M. Jantzen, "The Product Consistency Test and its Role in the Waste Acceptance Process for DWPF Glass," Waste Management, Volume 1, 1989.

8. C. M. Jantzen, N. E. Bibler, D. C. Beam, "Development and Characterization of the Defence Waste Processing Pacility (DWPF) Environmental Assessment (EA) Glass Standard Reference Material (U)," Ceramic Transactions, Volume 39, 1994.

9. Radioactive Waste Forms For Future, Editors: Werner Lutze and Rodney C. Ewing, North-Holland Publications, 1988. 


\section{KEYWORDS}

Paper Title: Candidate Glass-Ceramic Waste Forms For immobilization of the Calcines Stored at the Idaho Chemical Processing Plant

Author: K. Vinjamuri

Paper Number: SXI-35-95

Meeting: American Ceramic Society 97th Annual Meeting \& Exposition, Cincinnati, April 30May 3, 1995.

Glass-Ceramic

Glass

Calcine

PCT

MCC-1

EA Glass

ARM Glass

Young's Modulus

Chemical Durability

Microstructure

Soil

Waste Forms

Synthesis of glass-ceramics 